\title{
The Ontario Photonics Education and Training Association (OPETA): I'Union fait la Force!
}

\section{Marc Nantel}

Marc Nantel, "The Ontario Photonics Education and Training Association (OPETA): I'Union fait la Force!," Proc. SPIE 9663, Eighth International Topical Meeting on Education and Training in Optics and Photonics, 96631A (6 October 2003); doi: 10.1117/12.2207494

SPIE Event: Eighth International Topical Meeting on Education and Training in Optics and Photonics, 2003, Tucson, Arizona, United States 


\title{
The Ontario Photonics Education and Training Association (OPETA): I'Union fait la Force!
}

\author{
Marc Nantel \\ Photonics Research Ontario, Suite 331, 60 St-George Street, Toronto, ON, Canada M5S 1 A7 \\ (416)978-3932, (416)978-3936 (fax),mnantel@pro.on.ca
}

\begin{abstract}
OPETA regroups all parties interested in the supply of highly-qualified photonics personnel in Ontario. The association counts more than 60 members from Ontario's universities, community colleges, grade/mid/high schools, government agencies, private curriculum developers/providers and industry. In its third year, with a list-serv, webpage, regular meetings and coming off distributing to its members $\sim$ \$3-million in donated equipment, OPETA is a key element in local networking, helping photonics education flourish in Ontario at all levels.

(C)2003 Optical Society of America

OCIS codes: (000.2060) Education, (000.1200) Announcements, awards, news, and organizational activities
\end{abstract}

\section{Introduction}

Photonics is to be in the 21 st century what electronics was in the $20^{\text {th }}$, and it is often called "the next multi-trilliondollar industry". But one could say that - more than an industry - photonics is a key enabling technology that cuts through all industry sectors, from medicine to manufacturing, from research to consumer products, from art to telecommunications. It is certainly a crucial strategic technology for Canada, and for Ontario in particular. So why are so few people educated and trained to work in photonics? And what can be done about it?

These two questions are the basis for the formation of OPETA, the Ontario Photonics Education and Training Association (www.opeta.ca). In Ontario, where technology giants like Nortel Networks and JDS Uniphase rub shoulders with a growing number of feisty small-and-medium photonics companies, the demand for highly-qualified personnel in photonics - at all levels - much outstrips the supply. One of the reasons for this problem is that most photonics experts are produced in Ontario universities' graduate schools, with few ever touching a laser or optical fibres before that. This modus operandi yields too few workers in too narrow a slice of society to fill all the positions, which range from assemblers to technicians to engineers to researchers. As this pressure for more photonics-knowledgeable workers grew through the end of the 1990s, several educational institutions and private trainers have put together courses, programs, workshops and seminars in photonics to respond as best as possible. It quickly became clear that many of these efforts had to face similar challenges - among which developing new curriculum, finding qualified instructors, petitioning companies and governments for support, and recruiting students - and that banding together would benefit everybody, including industry and the students. This paper presents a successful model for networking, as applied to the photonics education and training community in Ontario, Canada. It is hoped that it can be used as a blueprint for others to start similar associations worldwide, and to enable networking of photonics education and training experts on a global scale through the nascent Global Photonics Education Network (GPEN), which is the subject of another paper in these proceedings [1].

\section{Out of chaos came (a semblance of) order...}

At the end of the 1990s, there was such a strong demand in Ontario - and indeed, worldwide - for workers qualified in photonics that much pressure was applied by the industry on the education system to provide said workers. With the seemingly unending exponential growth of the telecommunications industry in particular, large companies like JDS Uniphase, Nortel Network, Alcatel, and GSI Lumonics were in dire need for personnel at all levels, from assemblers to technicians to scientists. This human resource crisis was only exasperated by an increasing number of start-up companies with staggering growth, most of which were well funded by the venture capital community. These start-ups were in desperate need of R \& D scientists to bring their new products to market and establish themselves before their next round of financing. Add to this the increasing use of photonics in other industries like automotive, biomedical, manufacturing, etc., and one was faced in the province with a bottleneck to the growth of the sector resting on the availability of highly-trained photonics personnel. At one point, more than $40 \%$ of the Toronto Stock Exchange's TSE 400 index was dominated by telecom-related stocks [2], so this was no light matter and it needed to be addressed quickly. 


\subsection{A bevy of new programs in photonics education and training}

It was in this fertile ground that several new education and training programs in photonics independently started in 1999-2001, before the full telecom downturn had a chance to take hold. Addressing the need for technicians and technologists, Photonics Research Ontario (PRO, Toronto), Niagara College (Welland) and Algonquin College (Ottawa) established together 2- and 3-year programs at the colleges in a 4-year, \$7.6-million curriculumdevelopment and implementation project mostly funded by industry and the government of Ontario. Vitesse (ReSkilling) Canada (Ottawa), the Canadian Microelectronics Corporation (CMC, Kingston), the University of Toronto's Professional Development Centre (PDC, Toronto), the University of Waterloo's epSTAR (Waterloo) and Algonquin College were starting continuing education programs to provide photonics top-ups for scientists and engineers already possessing degrees to facilitate their slide into this sector with huge personnel demands. McMaster University (Hamilton), Carleton University (Ottawa) and Wilfrid Laurier University (Waterloo) were putting together full-blown undergraduate degrees and specializations in photonics through their Engineering, Physics and Physics/Computer departments, respectively, to address the need for engineers and scientists.

All the while, graduate schools at most large Ontario universities (Toronto, McMaster, Waterloo, Ottawa, Carleton, Western Ontario, Queen's) were increasing their research programs in photonics. This was in great part enabled through recent additional funding opportunities in Canada and Ontario stemming from the improved financial situation of the country. On the first year in decades that Canada posted a budgetary surplus (in 1997), \$800-million of it - a significant portion - was earmarked for the creation of the Canada Foundation for Innovation (CFI) to help with research infrastructure. Provincial matching funding agencies were started in many provinces to facilitate the access to CFI for its university professors. Many new photonics-related research programs were started or enhanced through this new source of funding, and through a better funded Natural Sciences and Engineering Research Council (NSERC).

\subsection{More confusion than solution?}

All this effervescent activity featuring several new players in photonics made for a rather confusing state of affairs from industry's and the student's points of view: What are all these programs? Which one is best for my needs? What are the differences between them? Adding to this was the general feeling of suspicion with which several of these educational institutions eyed each other: What are these other programs? Are they going to target the same student pool as ours? How are we in competition? Because of Photonics Research Ontario's privileged position as the Ontario Centre of Excellence mandate to support the growth of photonics in the province, it was involved - in one way or another - with most of these new education and training programs. In order to clear the air and focus the various stakeholders on the main task at hand - providing high-quality photonics workers to industry a "summit" of all known non-graduate programs providers was called by the author, who is the Manager of Photonics Education and Training at PRO, for 6 June 2001. At this "summit", participants from universities, colleges and independent curriculum providers exchanged information about their respective programs and networked extensively. It was quickly realized that each had much more in common than was thought, including the challenges ahead of teachers and students recruitment, and access to resources and funds. A main point emphasized at the "summit" was the almost non-existent voice the photonics education and training community had in the spheres of politics and the general public. In light of all this and the success of the "summit", all participants agreed to form an association to pursue together the common goal of providing photonics education and training in Ontario. Thus was born the Ontario Photonics Education and Training Association, or OPETA.

\section{OPETA: a photonics education and training "cluster"}

In the beginning, OPETA was little more than 14 people from 9 institutions, held together by a desire to establish good, solid programs in photonics. Even as such, OPETA was the start of a photonics education "cluster". A cluster is a group of local companies, educational institutions and other stakeholders rallying around a particular sector of the economy or industry [3]. By pooling resources, a cluster can network, share best practices, influence local politics, and lobby provincial, state or federal levels of government. One of the essential aspects of a cluster is that it be local, regrouping members from within, say, a 50-100-km radius (in OPETA's case, this is expanded to the whole of the province of Ontario). In photonics, the industry clustering efforts worldwide have been led by Dr. Bob Breault from Breault Research Organization in Arizona (USA). There exists now photonics industry clusters throughout the world [4]. Example of photonics education clusters include the National Association for Photonics Education and Training (NAPET) in Singapore and Project PHOTON in New England (USA). One of the main 
tenets of clustering is that even competitors are better served working together for the growth of the whole of their sector, to increase the pie - so to speak - instead of solely trying to get a bigger piece of a constant-size pie.

Because networking is a key component of a cluster's activities, much effort was spent in the early days of OPETA to establish efficient and successful means of communications, both internal and external. These are centered around a three-pronged approach including regular face-to-face meetings, a list-serv, and a webpage.

\subsection{Regular OPETA meetings and Mission/Vision statements}

The most important regular events staged by OPETA are its meetings. These were held for the OPETA members to network face-to-face every 3-4 months, rotating throughout the province. Thus far, meetings were held in Waterloo (inaugural "summit"), Hamilton, Niagara, Ottawa (first Annual Meeting), Toronto, Hamilton, London (second Annual Meeting). Much gets accomplished in these meetings, including setting the priorities for the year, striking committees to address particular issues or events and keeping each other informed of recent progress in our programs.

One of the first things on OPETA's plate was to establish what its priorities and goals were, in essence what its Vision and Mission were. Through the first two meetings, the following Vision and Mission statements were hammered together:

Vision: To foster, through its members, the provision of world-class education and training for all photonics needs in Ontario.

OPETA intends to achieve its vision through five Mission Statements:

1. Coordinating and leveraging Photonics Education and Training (PET) efforts;

2. Facilitation exchange and collaboration between educators;

3. Promoting PET to industry and government;

4. Outreaching to schools and the general public; and

5. Interacting with all stakeholders to assess and analyse the needs in photonics education.

Based on these Vision/Mission statements and the on-going projects, the draft agenda to each meeting is set by the Chair (the author, since OPETA's inception), with input from the membership. After the usual bookkeeping items (welcome, review of the agenda, review of last meeting's minutes), each member present gives a short (5-10 minutes) update of his/her activities, time is allowed for networking, and particular issues are tackled (Annual Meeting, organization, webpage update, equipment donations, etc). Meetings are usually scheduled as half-day events, with lunch and coffee breaks provided by the host institution or OPETA's budget.

\subsection{The OPETA list-serv and webpage}

The second means of direct communications established in the week following OPETA's inaugural meeting was the list-serv. A list-serv is a single email address to which a member from the list sends an email that will reach all the other members of the list. It is the simplest way to reach everybody at the same time. When meetings have to be set, policy has to be discussed, new resources have to be publicized, it is a very useful tool. There is usually a listserv manager who screens new applicants for relevance, but individual postings on the list are not routinely screened, they go directly to the list members. A general etiquette has to be followed when using list-servs to avoid mass mailing intended to only one member, or to avoid spam. There are several commercial but free list-serv providers where all the exchanges are archived and can be accessed only by the members of the list; OPETA uses Topica.com and has had great success with it. The most glaring limitation encountered with Topica is a 100-kilobyte message maximum, which greatly reduces the possibility of sending attachments. Nonetheless, in its $2+$ year of existence, the OPETA list-serv has conveyed more than 300 messages between members, making it OPETA's most important link between members.

In order to have a web presence for the outside world, OPETA established its webpage at www.opeta.ca. The webpage serves as a resource centre for the members, with documents, links, forms and other information posted for their viewing. The webpage also serves as a recruiting tool. It is currently in the process of being revamped. 


\section{The importance of coming together}

Of course, the explosion of photonics education and training programs that led to the formation of OPETA mostly took place before the current - and soon ending? - telecom slow-down. Some of these programs were mothballed or considerably altered in view of the change in demand from that dominating sector of the Ontario economy. The main issues that motivated the start of OPETA:

- How can we work together to answer this immediate mammoth human resource need?

- How can we secure an affordable supply of instructors when they are all being hired by industry?

- How will we be able to pay for the costly equipment needed to teach this technology?

were soon replaced by others:

- How do we adjust our curriculum to answer the demand from different sectors (manufacturing, biomedical, lighting, automotive)?

- How do we find our graduates good jobs?

- How do we ensure the long-term viability of our programs for such a time as when the demand increases again?

- How can we best leverage the industry's woes into something constructive for us and the sector in general?

Again, the power of association was evident in this critically different climate. As of August 2003, OPETA counts 66 members from 46 organizations (academic, governmental and industrial, see Table 1 for the list). In the sections below are some examples of accomplishments by OPETA as a whole and individual members.

Table 1. OPETA member organizations, as of August 2003, showing the diversity in geographical representation (all of Ontario, some in Nova Scotia and one in Scotland), educational levels (Outreach, Grade/Mid/High Schools, Colleges, Universities, Continuing Educations) and sectors (educational, governmental, industrial).

\begin{tabular}{|c|c|c|}
\hline Colleges & Government|Clusters & Continuing Education Providers \\
\hline $\begin{array}{l}\text { Algonquin College } \\
\text { (Ottawa, Ontario) }\end{array}$ & $\begin{array}{l}\text { Canadian Microelectronics Corporation } \\
(\mathrm{CMC})\end{array}$ & epSTAR \\
\hline $\begin{array}{l}\text { Canadian College of Business and Computers } \\
\text { (Toronto, Ontario) }\end{array}$ & $\begin{array}{l}\text { Centre for Microelectronics Assembly and } \\
\text { Packaging (CMAP) }\end{array}$ & Lightguide Systems \\
\hline $\begin{array}{l}\text { Durham College } \\
\text { (Oshawa, Ontario) }\end{array}$ & Canadian Photonics Consortium & Physiciens Sans Frontières \\
\hline $\begin{array}{l}\text { George Brown College } \\
\text { (Toronto, Ontario) }\end{array}$ & $\begin{array}{l}\text { Department of Foreign Affairs and } \\
\text { International Trade (DFAIT) }\end{array}$ & Valkom \\
\hline \multirow[t]{2}{*}{$\begin{array}{l}\text { Niagara College } \\
\text { (Welland, Ontario) }\end{array}$} & Strategic Microeletronics Consortium (SMC) & Vitesse (Re-Skilling) Canada \\
\hline & $\begin{array}{l}\text { Ontario Ministry of Entreprise, Opportunity } \\
\text { and Innovation (MEOI) }\end{array}$ & \\
\hline Universities & $\begin{array}{l}\text { National Capital Institute for } \\
\text { Telecommunications (NCIT) }\end{array}$ & S \& T Outreach Organizations \\
\hline $\begin{array}{l}\text { Acadia University } \\
\text { (Wolfville, Nova Scotia) }\end{array}$ & $\begin{array}{l}\text { Industrial Research Assistance Program } \\
\text { (NRC - IRAP) }\end{array}$ & Let's Talk Science \\
\hline $\begin{array}{l}\text { Carleton University } \\
\text { (Ottawa, Ontario) }\end{array}$ & $\begin{array}{l}\text { Ottawa Centre for Research and Innovation } \\
\text { (OCRI) }\end{array}$ & Scientists in School \\
\hline $\begin{array}{l}\text { Dalhousie University } \\
\text { (Halifax, Nova Scotia) }\end{array}$ & Ottawa Photonics Cluster (OPC) & $\begin{array}{l}\text { Science and Technology Awareness Network } \\
\text { (STAN) }\end{array}$ \\
\hline $\begin{array}{l}\text { McMaster University } \\
\text { (Hamilton, Ontario) }\end{array}$ & $\begin{array}{l}\text { Ontario Photonics Technology Industry } \\
\text { Cluster (OPTIC) }\end{array}$ & \\
\hline $\begin{array}{l}\text { Strathclyde University } \\
\text { (Glasgow, Scotland) }\end{array}$ & Photonics Research Ontario (PRO) & Grade/Mid/High Schools \\
\hline $\begin{array}{l}\text { University of Guelph } \\
\text { (Guelph, Ontario) }\end{array}$ & $\begin{array}{l}\text { Ontario Research and Development } \\
\text { Challenge Fund (ORDCF) }\end{array}$ & $\begin{array}{l}\text { The City School } \\
\text { (Toronto, Ontario) }\end{array}$ \\
\hline $\begin{array}{l}\text { University of Ottawa } \\
\text { (Ottawa, Ontario) }\end{array}$ & $\begin{array}{l}\text { Ontario Institute for Studies in Education } \\
\text { (OISE) }\end{array}$ & $\begin{array}{l}\text { Dennis Morris High School } \\
\text { (St Catharines, Ontario) }\end{array}$ \\
\hline $\begin{array}{l}\text { University of the Ontario Institute of } \\
\text { Technology (Oshawa, Ontario) }\end{array}$ & & $\begin{array}{l}\text { John Paul II Catholic Secondary School } \\
\text { (Scarborough, Ontario) }\end{array}$ \\
\hline $\begin{array}{l}\text { University of Toronto } \\
\text { (Toronto, Ontario) }\end{array}$ & Companies & $\begin{array}{l}\text { Queensway Christian College } \\
\text { (Toronto, Ontario) }\end{array}$ \\
\hline $\begin{array}{l}\text { University of Waterloo } \\
\text { (Waterloo, Ontario) }\end{array}$ & Air Products and Chemicals & $\begin{array}{l}\text { Toronto District School Board } \\
\text { (Toronto, Ontario) }\end{array}$ \\
\hline $\begin{array}{l}\text { Wilfrid Laurier University } \\
\text { (Waterloo, Ontario) }\end{array}$ & JDS Uniphase & $\begin{array}{l}\text { University of Toronto Schools } \\
\text { (Toronto, Ontario) }\end{array}$ \\
\hline
\end{tabular}




\subsection{Toward an integrated photonics education and training continuum}

Three years ago, in 2000, there were no undergraduate programs in Ontario exposing students to optics, lasers and photonics more in-depth than the usual "Optics and Waves" or "Electromagnetic Theory" courses in the Physics, Chemistry and Engineering departments. There certainly were no complete programs targeting photonics. With its first foray into the community college system, Photonics Research Ontario drew up a plan to establish a continuum of photonics education, "from grade school to grad school" as it became known. Figure 1 shows the pyramid on which this continuum is based. Traditionally, students were not being exposed to lasers until entering graduate school in Physics, Chemistry or Engineering. Not only is this too late in the education pyramid, but this modus operandi only offer Master's and PhDs as photonics experts, failing to address the other levels. A comprehensive solution to the demand for photonics experts starts with more grade-school and high-school students being exposed to optics; with more parents and high-school career counselors knowing about photonics and recommending it as a career. Hence, a strong community awareness effort is needed, through print, radio and TV media. Full photonics programs have to be implemented at all post-secondary levels, in community colleges and at universities. For those already in the workforce needing a top-up in photonics, continuing education or crash courses in photonics (such as laser safety courses) need to be available.

In order to know where photonics education leads, what is also needed are clear career paths resulting from Photonics Technician and Technologists diplomas from community colleges, Bachelors of Science and Engineering in Optics from universities, or re-training opportunities for already-employed high-tech workers. While some of these types of programs are found in a few areas in North America, access to a comprehensive suite of programs in photonics is still limited (Rochester, NY, is a rare example, with Monroe Community College, the Rochester Institute of Technology and the University of Rochester all offering programs in photonics/optics; the Québec City region is also blessed by programs at the cégeps de la Pocatière, de Limoilou and at Université Laval). Figure 2 shows the various education paths desirable to have in photonics. A student coming from high school should have the choice of getting a photonics education through the university or the college paths. A worker wanting to learn about photonics should have the choice of a professional education program or one customized for specific needs. A new graduate or third-year undergraduate university student in a non-photonics degree should be able to take a crash course in the summer (after graduation or before his/her last year).

This kind of integrated approach to education in any particular sector requires the buy-in from all the levels of education. This is why a cluster like OPETA is critical to this endeavor. By coming together and working toward the same goal, OPETA members have now covered the whole of this pyramid, as shown in Table 2. In particular, the networking through OPETA has enabled important partnering between institutions and facilitated articulations between the new programs to allow for the movement of students graduating from one program into another. Most of the programs listed in Figure 2 did not exist before 2001. Most have been greatly enhanced by their association with OPETA through networking, letters of support during funding or program proposals, equipment donations, etc...

Of particular interest in Table 2 is the development of full-blown bachelor's degrees in photonics. Two universities and two colleges are going to establish in 2003-2004 programs with the final credential of bachelor's in photonics.

McMaster University's new Photonics Engineering program will be offered by the Department of Engineering Physics, and will be the first Engineering program of its kind in Canada. Like the existing Engineering Physics program, it will provide students with a broad background in basic Engineering, Mathematics, Electronics, and Semiconductors. However, the new program will provide students an opportunity to pursue Photonics in greater depth and to have that fact recognized in the program designation. Following McMaster's successful pattern of fiveyear Engineering programs, a new B.Eng. in Photonics Engineering and Management and another in Photonics Engineering and Society will be introduced in parallel with the four-year program. The first students are expected to enter Level II in September 2003, with the first class graduating in the spring of 2006.

Wilfrid Laurier University's Department of Physics and Computer Science is launching its new Honours B.Sc. Photonics with its first student intake in September 2003. The aim of the program is to develop a strong understanding of the theory and application of photonics, with specific emphasis on data communications and networks, and with practical hands-on exposure to optics, fibre optics, and lasers. Wilfrid Laurier University's program benefits from the particularity that the department offering it combines both Physics and Computer Science, and that the thrust of the program would reflect this combination. 


\section{Work Force Credential Educational Institution}

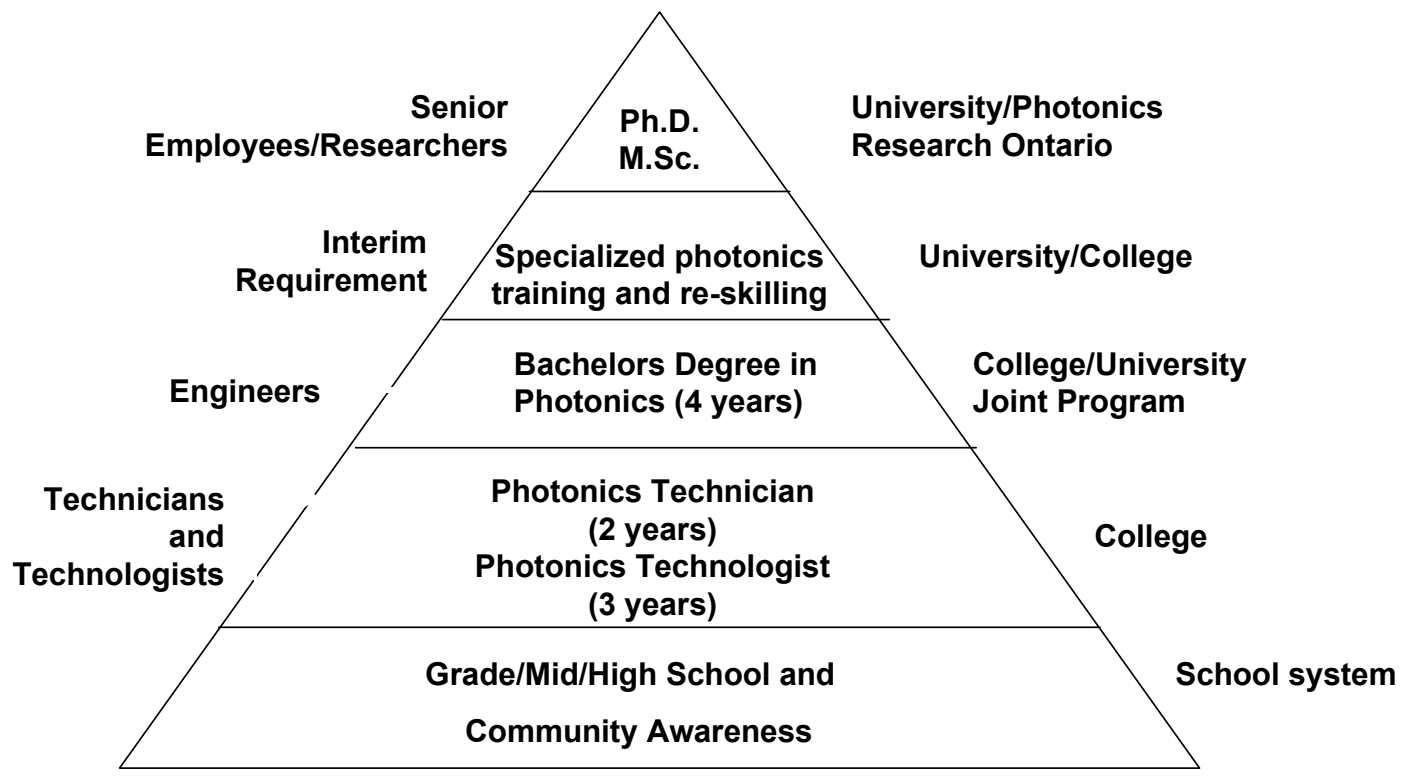

Fig. 1. The photonics education and training pyramid. Photonics should be taught at all levels, "from grade school to grad school". Significant efforts also have to be deployed outside of the traditional school system to reach the general community and to provide continuing education on the subject. Only then can one provide photonics technicians, engineers and scientists: through the programs in place and through a constant "priming of the pump" at the base of the pyramid to continually get new recruit to enter the pipeline.

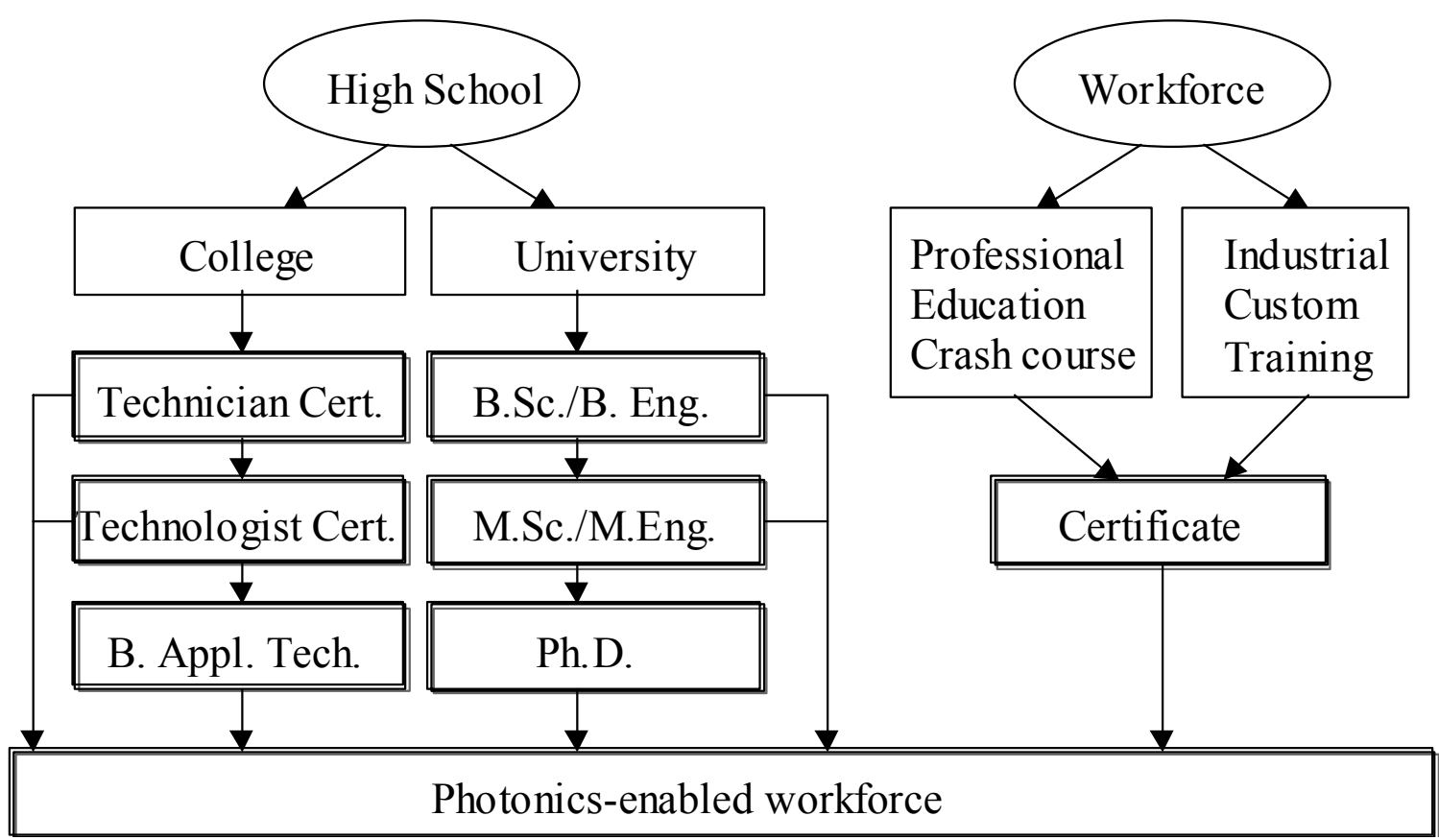

Fig. 2. It is also important to provide clear career paths and articulations between programs to increase the number of choices available to people interested in entering the photonics education and training stream. Good choices and flexibility throughout the education continuum are essential to augmenting the number and quality of highly-qualified photonics personnel in the workforce. 
Table 2. New programs or enhancements of existing programs undertaken by OPETA members

\begin{tabular}{|c|c|c|c|c|}
\hline Programs $\mid$ Year Started & 2001 & 2002 & 2003 & 2004 \\
\hline $\begin{array}{l}\text { Professional } \\
\text { Development }\end{array}$ & $\begin{array}{l}\text { U. Toronto's PDC } \\
\text { Algonquin } \\
\text { College }\end{array}$ & $\begin{array}{l}\text { Vitesse (Re-Skilling) } \\
\text { Canada } \\
\text { epSTAR } \\
\text { CMC }\end{array}$ & $\mathrm{CCBC}$ & \\
\hline $\begin{array}{l}\text { B.Sc. } \\
\text { B.Eng. } \\
\text { Specializations } \\
\text { B.Appl.Tech. }\end{array}$ & & & $\begin{array}{l}\text { Wilfrid Laurier U. } \\
\text { (B.Sc.) } \\
\text { McMaster U. } \\
\text { (B.Eng.) } \\
\text { Carleton U. } \\
\text { (specialization) }\end{array}$ & $\begin{array}{l}\text { Algonquin } \\
\text { College } \\
\text { (B.Appl.Tech.) } \\
\text { Niagara College } \\
\text { (B.Appl.Tech.) }\end{array}$ \\
\hline $\begin{array}{l}\text { Technologist and } \\
\text { Technician }\end{array}$ & $\begin{array}{l}\text { Algonquin } \\
\text { College } \\
\text { Niagara College }\end{array}$ & & $\begin{array}{l}\text { George Brown } \\
\text { College }\end{array}$ & \\
\hline $\begin{array}{l}\text { Grade/Mid/High } \\
\text { School } \\
\text { Community Awareness }\end{array}$ & $\begin{array}{l}\text { Discovery } \\
\text { Channel segments } \\
\text { by PRO }\end{array}$ & $\begin{array}{l}\text { Scientists in School } \\
\text { (PRO-enhanced) } \\
\text { Let's Talk Science } \\
\text { (PRO-enhanced) } \\
\text { SLOME } \\
\text { (PRO-enhanced) } \\
\text { PRO Optics Kits } \\
\text { Program }\end{array}$ & $\begin{array}{l}\text { Science and } \\
\text { Technology } \\
\text { Awareness } \\
\text { Network (STAN) }\end{array}$ & \\
\hline
\end{tabular}

Niagara College and Algonquin College, already strong from their programs in Photonics Engineering Technician/Technologists, have been given permission by the Ontario Ministry of Training, Colleges and Universities to offer a 4-year Bachelor of Applied Technology (Photonics). The concept of 4-year degrees at the community-college level is a new one in Ontario, and competition was fierce in obtained the few allowed permissions. The college program is joint between the two institutions, with a common curriculum, shared library resources, student exchanges between the two colleges and co-op work-terms. Emphasis is placed on the applied aspect of the field, with the more hands-on experimental learning taking precedence in the first years and the more advanced theoretical subjects following in the latter years. This is a reversal from the usual sequence in a degree program, and the merits of this approach will be discussed. This program is in preparation for a first student intake in September 2004.

Another interesting development due in part to OPETA is the birth of the Science and Technology Awareness Network (STAN) in Ontario. This group, which effectively makes up a "science and technology outreach cluster", is inspired by the success of OPETA and models itself after it. It regroups 56 members from the science and technology outreach community in Ontario. While not focusing on photonics per se, the work that its members do will increase the profile of science and technology with grade/mid/high school students as well as with the general public.

\subsection{Facilitating equipment donations}

The unfortunate - and temporary - downturn in the telecommunications sector in 2001 left several OPETA members scrambling to re-organize their programs to ensure that their students would be able to find good jobs upon graduation. Other programs were scaled down or put on the back burner. One of the silver lining of this otherwise 
deplorable situation was the sudden availability of millions of dollars in telecommunications equipment for educational institutions. As giant corporations were shedding inventory, some tried their best to be good corporate citizen and donated to colleges and universities. In one such example, JDS Uniphase, in Canada, distributed several million dollars in used and new equipment to 14 Canadian universities and colleges in 2001-2002. Coordinating such a complex donation - including $3{ }^{\text {rd }}$-party valuation, packaging, delivery - required a considerable amount of JDS resources. Because of that, when a new wave of equipment was deemed available in Summer 2002, it would have been tempting for JDS to crush it instead of going through the effort of donating it...

Thankfully, astute OPETA members worked out a process by which JDS Uniphase would donate all this equipment to one source - OPETA - who would then take care of the valuation, handling, storing, and distribution to its members. By providing a one-stop recipient for JDS Uniphase, OPETA received in late Summer 2002 in excess of \$3-million in equipment. Once the equipment had been moved out of the Ottawa JDS facilities and stored at Algonquin College and Carleton University, a $3^{\text {rd }}$-party valuation was undertaken, a call for proposal was launched and a competitive disbursement process was put in place to distribute the equipment fairly to all OPETA members interested. Eight proposals were received in Winter 2003, and an ad-hoc Donation Advisory Group was formed from OPETA members who did not submit proposals. By July 2003 - about one year after the beginning of the whole process - all the equipment had been distributed to the successful proponents. Among them were 5 universities, 2 community colleges, 1 private college and an outreach organization. This equipment is going a long way to enable several of the programs listed in Table 1. OPETA is currently in the process of securing another similar donation from another large photonics company.

\subsection{OPETA as a spoke for the Global Photonics Education Network}

There is a new networking effort being undertaken to link photonics educators from around the world, the Global Photonics Education Network (GPEN). Founded at the ETOP 2001 conference in Singapore, this group aims to facilitate the exchange of ideas, information and resources between educators globally to help with the implementation and delivery of photonics education and training programs locally. While the GPEN is still in its early days, it has been identified early that photonics education clusters such as OPETA, NAPET and Project PHOTON can act as ideal portals from the local to the global arenas. Already, members of all three of these clusters are part of the GPEN, and it is hope that other such local education clusters can see the light of day elsewhere in the world. See the GEPN paper in these proceedings [1].

\section{Conclusion}

In this paper we present the Ontario Photonics Education and Training Association (OPETA) as a model for the local networking of educators in the specific field of photonics. OPETA started out of a necessity to organize a rapidly growing number of photonics education and training programs in Ontario. Going from 14 members representing 9 institutions to 66 members from 46 institutions in 2 years, OPETA has proven itself a valuable tool for networking, advocacy to industry and government, equipment donations and program coordination beyond the original expectations of the founding members. By including all levels of education, from grade school to grad school, as well as government agencies and photonics companies, OPETA strives to further its vision of fostering, through its members, the provision of world-class education and training for all photonics needs in Ontario.

\section{Acknowledgements}

OPETA and the author are funded in part by the Ontario Ministry of Entreprise, Opportunity and Innovation's Strategic Skills Investment Program and wish to acknowledge this support.

\section{References}

[1] C. Roychoudhury and M. Nantel, "The Global Photonics Education Network: Another Way to Think Globally and Act Locally", in these proceedings.

[2] M. Nantel and J. Beda, "Photonics Education and Training in Ontario", Phys. Can. 58, 19 (2002).

[3] M.E. Porter, "Clusters and the New Economics of Competition", Harvard Business Review, Nov-Dec. 1998 (1998).

[4] See for example: the Arizona Optics Industry Association (www.aoia.org/AOIA/), the Florida Photonics Cluster (www.floridaphotonics.com), the Ontario Photonics Technology Industry Cluster (www.optic.on.ca), the Ottawa Photonics Cluster (www.ottawaphotonics.com), the Midland Photonics Cluster (www.midlandsphotonicscluster.org), Optics Valley France (www.opticsvalley.org), Bayern Photonics e.V. (www.bayernphotonics.de), Australia Photonics CRC (www.photonics.crc.org.au), Optics Valley China (www.chinaov.org), and the cluster directory at www.photonicsclusters.org/cluster-list.dxp. 